\title{
The Transformation of Normative Approaches to Journalism in Croatian Academic Literature from Socialism to Post-Socialism
}

\author{
DINA VOZAB, DUNJA MAJSTOROVIĆ \\ Faculty of Political Sciences, University of Zagreb
}

\begin{abstract}
Summary
This paper shows changes in the normative expectations of journalism through an analysis of articles published in Croatian scientific journals about journalism in three time periods: socialism, the transition period, and the period of democratic consolidation. Using qualitative content analysis we identify a total of fifteen themes related to journalism (journalistic norms, regulation, sensationalism, investigative journalism, journalism and PR, organizational aspects, war reporting, technological aspects, gender and journalism, media freedom, democratic aspects, economic aspects, journalism education, the function of journalism in a political system, and the history of journalism) and nine normative roles for journalists (gatekeeper, social-political worker, public sphere promoter, watchdog, commercial role, emancipatory role, neutral disseminator, advocacy role, defender of democracy). We used quantitative content analysis to analyze the distribution of themes and roles. The results show no unambiguous perception of journalism in academic papers during the different time periods as is generally assumed in the literature on media democratization and the media in transitional countries in general.
\end{abstract}

Keywords: Content Analysis, Journalism, Post-Socialism, Social Science Journals, Socialism

\section{Introduction}

Journalism is often thought of in terms of its "professional ideology" (Deuze, 2005) and liberal or the "Anglo-american" model (Chalaby, 1998, as quoted in Schudson and Anderson, 2009, p. 93). Although these models are widely accepted in Western democracies, journalism norms, ethics and practices are diverse and changing in different cultural and political contexts (Hanitzsch et al., 2011), and also change 
through time, intertwined with social, political or technological change. The goal of this paper is to show how the transition of journalism through different political systems is perceived in the academic literature. As academic texts often describe and reflect normative expectations of journalism, this analysis will also offer an insight into the role the academic elite plays in the transition process and the normative understanding of the role of journalism in different political systems.

Our research draws on the previous analysis of the development of the discipline of communication in Yugoslavia (Splichal, 1989) and Croatia from the socialist period to the post-socialist period (Peruško and Vozab, 2014), but instead of analyzing the entire academic production in media and communication, we focus on academic work that explores or defines the journalism profession. The results are divided into three periods: 1) socialism (from $1969^{1}$ to 1990) - the period when Croatia was one of six republics in the Socialist Federal Republic of Yugoslavia, 2) transition (the 1990s) - the period after 1991 and independence from SFR Yugoslavia when Croatia became a democracy ${ }^{2}, 3$ ) and consolidation ${ }^{3}$ - the period after the elections in 2000 that overthrew the ruling political party and implemented the changes in the political system from a semi-presidential to a parliamentary system.

Research on the changes of journalism roles during the post-socialist transition has so far dealt with the role of journalists that entered the profession before, during and after the transformation of the political system in Poland (Stępińska and Ossowski, 2012), or the perceptions of journalism roles in the Western Balkans (Andresen, Hoxha and Godole, 2017). Since the role of academic literature in defining journalism roles in post-socialist transition has not been thoroughly researched, this paper is designed to fill this gap in the literature and examines the perception

1 The first year that defines the socialist period in SFRY is 1945, but in this case 1969 was chosen due to the beginning of development of journalism education and communication discipline in Croatia. In 1969 journal Informatologia, devoted to information science and which had a significant influence on the development of media and communication discipline was established in Croatia (Peruško and Vozab, 2014, p. 138). The first one-year and two-year education programs of journalism at the University of Zagreb started in the beginning of the 1970s (Peruško and Vozab, 2016, p. 219).

2 The political regime in the transitional period is labelled as "simulated democracy" (Boduszynski, 2010, p. 74), "authoritarian democracy" (Čular, 2000, p. 37) or "defect democracy" (Zakošek, 2008, p. 600), which means that certain aspects or procedures of the democratic system were accepted, while keeping some important aspects of the illiberal or authoritarian political regime.

${ }^{3}$ In transition theory consolidation comes after transition and marks a slow but purposeful process in which democratic forms are transformed into democratic substance through the reform of state institutions, the regularization of elections, the strengthening of civil society, and the overall habituation of the society to the new democratic "rules of the game" (Carothers, 2002, p. 7). 
of journalism roles by academia with the example of post-socialist Croatia. Academic interest for the field of journalism in Croatia developed later in comparison to Western Europe due to the late introduction of journalism studies at universities in the former Yugoslavia. The introduction of specialized journalism courses in faculties of political science in the late 1960s in Ljubljana, Belgrade and Zagreb and the opening of a journalism department at the Ljubljana Institute of Sociology in 1962 marked the academic institutionalization of communication science in Yugoslavia (Splichal, 1989, pp. 342-343). Though the first academic study of journalism was established in Croatia in the early 1970s, the first four-year study of journalism began as late as 1985, again at the Faculty of Political Sciences in Zagreb (Peruško and Vozab, 2014, p. 134). The late institutionalization of communication science resulted in the later establishment of specialized academic journals devoted to media and communication research.

This analysis will draw on a theoretical framework of media democratization and transition in post-socialist countries (Splichal, 1994; 2001) as well as on the conceptualization of journalism as a social field (Benson, 1998) or professional milieu (Hanitzsch, 2011).

\section{Approaches to Media Transition from Socialism to Democracy}

Journalism and media are considered institutions integrated into the political system by normative theories of press and media (Christians et al., 2009; Siebert, Peterson and Schramm, 1956) and theories which emphasize a press-politics relationship in media systems (Blumler and Gurevitch, 1995; Hallin and Mancini, 2004). Democratization theory and the transitology perspective in political science ${ }^{4}$ has been used to explain and describe changes in third wave democracies, while also serving as a framework in many academic articles about media reforms and media transition in post-communist and post-socialist Europe. The media reforms were perceived as a rather linear process which aimed at abolishing or limiting state influence in media systems, constituting legal frameworks that guarantee freedom of speech, decentralizing and depoliticizing mass media, and enabling a greater professionalization and autonomy in journalism (Jakubowicz, 1996, as quoted in Coman, 2000, p. 36). Media in the process of democratization are studied as one of the tools of democratization and as institutions which should be democratized themselves (Jebril, Loveless and Stetka, 2015, p. 85). As tools of democratization, media were supposed to introduce and legitimize concepts of democracy, rule of law, constitutionalism,

4 Transitology or transition studies refers to the theoretical approach in political science, in studies of regime change from authoritarian to democratic. It gained prominence from studies of third wave democracies, first in Latin America and Southern Europe and later in post-communist and post-socialist countries (Gans-Morse, 2004, p. 322). 
political pluralism, party competition, civil society, even national integration and nation-building (Jakubowicz and Sükösd, 2008, p. 11), and transitional justice in cases where transition was followed with conflict like in the former Yugoslavia (Andresen, Hoxha and Godole, 2017). The liberal idea of media as a democratic institution consists of media providing a "marketplace of ideas", media having an informational function by providing quality information, encouraging debate, or mobilizing for political participation, having a role of watchdog, or performing as the fourth estate (Voltmer, 2006, p. 4). In broader models of democracy, like participatory or deliberative, journalists are also responsible for setting agendas and the framing of political issues, promoting the public sphere, enabling discussion, mobilizing and linking citizens to politics (Strömbäck, 2005). Research and analysis of media transition and the role of media in democratization in post-socialist societies usually dealt with freeing media from state control and media market liberalization, with the assumption that this will have a positive role for further democratization (Balčytienè, 2016; Peruško, 2013; Splichal, 1994).

However, the transitology literature or analysis based on normative assumptions is problematic for several reasons. Coman (2000) concluded that there is a lack in theoretical and conceptual development that would explain changes in media and journalism in Central and Eastern Europe. The diverse set of countries with different transitional trajectories are usually lumped together and the communist/ socialist period is often overemphasized like an overarching "independent variable" explaining different aspects of media systems in transition. Coman (Ibid., p. 49) criticizes these studies finding "roots in a super-state, supercultural and unhistorical perspective". Rather than developing models explaining processes of social change, the emphasis was on the normative theories (public sphere, four theories of the press) that were supposed to describe the expected outcome of the transition (Coman, 2000; Splichal, 2001).

Different authors describe and propose various processes and types of media transition. Gross (2004, p. 111) divides media transformations in three phases: the preparatory phase, which occurs amid the breakup of the communist regime, and is marked by the flourishing of alternative and anti-communist media; the transformation phase in which institutions are transformed to resemble the Western liberal democratic institutions; and the consolidation phase in which media institutions are stabilized and are in accordance to a democratic political system. According to Splichal (2001), guided by the normative expectations, media systems in postcommunist and post-socialist Europe experienced "imitative revolutions", uncritically embracing the policies emphasizing the laissez-faire approach to regulation, and the substitution of the former institutions and practices, while disregarding the specific social and cultural context and certain democratic practices that existed in the socialist period. 
Besides Splichal's (Ibid.) analysis of media transition in Central and Eastern Europe, more recent research and theoretical approaches step out of the normative assumptions in analyzing media transition. Empirical research on European media systems shows a large diversity of post-communist or post-socialist countries which cannot be put together easily into a distinct group, but rather share similarities with southern, central or western European countries (Peruško et al., 2013) and show a significant diversity in characteristics of their contemporary media system (Herrero et al., 2017). This diversity perhaps follows the diversity of different socialist regimes - comparative analysis delineated three distinct groups of socialist media cultures: the reformist state socialist system, hardline state socialist system, and the market state socialist system (Mihelj and Huxtable, 2018). Socialist Yugoslavia belonged to the latter type, with moderate party and state control of media, international orientation, and a specific self-management system which enabled strong elements of self-regulation and the commercial orientation of media (Ibid.; see also Robinson, 1977 for description of the media institutions' position between market and socialism in Yugoslavia). Research on journalism roles in the socialist and post-socialist period in Poland found a strong adherence to some "Western" norms in journalism even in the socialist period (Stępińska and Ossowski, 2012). This analysis will continue this strand of research by critically analyzing the change in normative assumptions and expectations of the journalism field during the different phases of the transition from socialism to market economy and liberal democracy.

\section{The Transition of the Journalism Field}

Another useful theoretical approach in the analysis of the transition in journalism is field theory. ${ }^{5}$ Benson (1998) draws on Bourdieu's field theory to develop the concept of the journalism or media field. The journalism field is more heterogeneous than other social fields as it is interconnected with the political and the economic fields. According to Benson (Ibid., p. 468), the autonomous pole of the journalistic field is defined by the rules of the journalistic profession, to which new entrants are socialized through journalism education; on the other hand, the heteronomous pole is where these rules and values conflict and overlap with other fields' logic. In other words, the journalism field's autonomy would correspond to the "professional identity and ideology" of journalism, based on values such as public service, objectivity, autonomy, immediacy and ethics, which are commonly taught in journalism studies

5 Field theory is developed by Pierre Bourdieu, and it perceives society "as differentiated into a number of semi-autonomous fields (e.g., fields of politics, economics, religion, cultural production, etc.) governed by their own 'rules of the game' and offering their own particular economy of exchange and reward, yet whose basic oppositions and general structures parallel each other" (Benson, 1998, p. 464). 
across Western democracies (Deuze, 2005). The prevalence of different aspects of journalism may define the journalistic field in a different way and make changes in the historical development of the field. Although this article explores the transition of journalism indirectly, through the academic perspective, the themes associated with journalism or the desired roles of journalists in different time periods might explain the changing nature of the journalism field. Moreover, the academic perspective is closely linked to the institution of journalism education, which is for most journalists a place of their primary socialization into the profession.

\section{Journalism Roles in Democracy and Beyond}

There are several theoretically recognized journalism roles, mostly the ones adhering to democratic political systems or Western models. The gatekeeper role was first defined by Lewin (1947, p. 145) as "an individual or a group 'in power' of making the decision between 'in' or 'out"'. The civic or public sphere role is where a "journalist educates the common citizen on complex and controversial topics and encourages people to get involved in public debate and participate in political events" (Voltmer, 2013, p. 26, as quoted in Mellado and Van Dalen, 2017, p. 246). The watchdog function is, according to Mellado and Dalen (Ibid.), particularly important during democratic transition in which media can take "a critical stance toward those in power" and hold "them accountable by giving attention to wrongdoings". The emancipatory role can be seen through the role of media and journalists as "either promoting participatory communication, or advancing the democratization of communication, or even encompassing modes of subversive action" (Vatikiotis, 2005 , p. 4). This role could be linked to the mobilizer role that puts an "emphasis on political involvement by proactively encouraging audience members to participate in the political domain" (Weaver et al., 2007, as quoted in Hanitzsch and Vos, 2018, p. 154). The advocacy function of the media and advocacy journalism role is the "strategic use of the mass media as a resource to advance a social or public policy initiative" (Pertschuk et al., 1989, p. 8, as quoted in Jernigan and Wright, 1996, p. 306). Advocacy can too be used for a journalist "acting as campaigner, as 'lobbyist', as a 'voice for the poor"' (Pintak and Nazir, 2013, p. 649, as quoted in Hanitzsch and Vos, 2018, p. 155).

Drawing on field theory, Hanitzsch (2011) analyses journalists' professional milieus and conceptualizes them as ones defined by perceptions, negotiations and consensus among journalists about the social roles they should be taking. Institutional roles differentiate according to journalists' interventionism, power distance and market orientation (Hanitzsch, 2007). An analysis of the perception of journalism roles across 18 countries revealed four global professional milieus: the populist disseminator, detached watchdog, critical change agent and the opportunist facilita- 
tor (Hanitzsch, 2011). The populist disseminator role is oriented towards the logic of commercial media, audience ratings and providing entertaining information to wide audiences. The detached watchdog adheres the most to the "professional ideology" of journalism as an independent watchdog of elites that provides information to citizens; the critical change agent is also defined as a watchdog, but with the important social change advocacy dimension; and the opportunist facilitator is in partnership with governments and elites, serving by providing their positive image (Ibid.). These professional milieus are generally culturally bounded: the detached watchdog is prevalent in Western democracies, while other ones, except populist disseminator which cuts across nations, are more prevalent in a non-western context.

The more recent research by Hanitzsch and Vos (2018) reveals the prevalence of journalism roles beyond democracies and the West. They define 18 roles in various political and media systems which serve six functions of journalism in the political system. The informational-instructive function pertains to the idea of journalist as disseminator of information in a more or less neutral manner - these are the roles of a disseminator, curator or storyteller. Analytical-deliberative function puts a journalist in a more interventionist role of empowering citizens for discussion or participation - as an analyst, access provider or a mobilizer. Critical-monitorial function adheres to the Western model of journalism as a "fourth estate", with journalists acting as monitors of those in power, as "detectives" or investigative journalists or as watchdogs. An advocative-radical function puts journalists in a position counter to power and with them also sometimes ideologically positioning themselves outside of the dominant ideology, like adversaries against political authority, advocates of certain social groups or missionaries of a cause or ideology (Ibid., p. 155). The developmental-educational function is interventionist, perceiving journalists as participating in or promoting social change, as change agents in transitional societies, educators or mediators between conflicting social groups. The collaborative-facilitative function makes journalists close to power, and advocates of power with a paternalistic approach towards citizens, like facilitators to government programs and policies which are seen as advancing the development of the country, collaborators which are perceived as a part of the state apparatus, and finally mouthpieces of government which give "legitimacy to the government by explaining political decisions to the people and guiding public opinion" (Lee, 2001, as quoted in Ibid., p. 156).

The role of journalists in socialism, and during socialist Yugoslavia, could be most closely related to their collaborative-facilitative function. Social-political worker is the name used for journalists in service of promoting self-management socialism, the unique form of socialism developed in Yugoslavia. The term itself is derived from the word social/socialism, as most of the ownership (in terms of pro- 
duction means) in Yugoslavia was not the state's, but the people's (society's). In Yugoslavia's Law on Public Informing from 1982, a journalist is named as a worker that has the right and duty to work on informing the public; engaged, socially and politically accountable, and as a professional who respects the ethics of the profession to achieve the interests and development of the socialist self-management community (Article 98, Law on public informing, 1982, p. 32). With the gradual liberalization of the Yugoslav media system, the role of the journalist was broadened to promote public debate using various sources of information (Zubak, 2018, p. 29). Moreover, as Zubak (Ibid., p. 28) also notes, the specific self-management system required well-informed workers who should be able to participate in decision-making processes in companies, so quality journalism was needed.

Andresen, Hoxha and Godole (2017) use the most recent Worlds of Journalism data to analyze the role perceptions of journalists in the Western Balkans. Their analysis shows that journalists in the Western Balkans highly value the detached watchdog role of journalism, but also strongly combine it with the critical change agent role putting emphasis on social change advocacy and national development. The type of the professional milieu points to its position in the journalism field, or its connection to other social fields. Although Hanitzsch (2011) analyses the geographical distribution and differentiation of journalism professional milieus, their differences and the dynamics of the journalism field can also be observed in the temporal dimension which this analysis is set to explore.

\section{Research on Journalism in Academic Articles}

This article is an attempt to analyze the normative approaches to journalism in academic literature, or to understand how normative definitions of the journalism field change between different political systems. The research is inspired by the study of the development of the communication discipline in Yugoslavia (Splichal, 1989) and is inspired by recent research of communication journals in Croatia (Peruško and Vozab, 2014). In this analysis, the journalism field is described through 1) thematic focus of articles associated with journalism; and 2) normative roles of journalists. The mostly exploratory and inductive approach in the research is taken through first qualitative and then quantitative analysis of academic texts on journalism.

The following research questions are set to guide the analysis:

RQ1) What were the prevailing thematic focuses of articles associated with journalism that appeared in the analyzed periods?

RQ2) What were the prevailing normative roles of journalists in the analyzed periods?

RQ3) Is there a change in the academic perception of journalism as a profession (through time and within different political systems)? 


\section{Method}

The methods used are qualitative and quantitative content analysis, with the largest emphasis on the qualitative analysis. Due to the specificity and the complexity of the examined material, which consists of academic articles, we chose to use qualitative content analysis in the first, exploratory phase of the research and quantitative content analysis in the second phase. The first qualitative phase of research enabled the inductive analysis, which resulted with two types of results: a) thematic focus on the aspects of the journalism profession and b) the ways in which academics define normative roles of journalists. In the quantitative phase, the authors used the categories defined in the first phase to measure their frequencies in the three analyzed periods.

Qualitative content analysis, as described by Schreier (2012), is used to systematically describe the meaning of qualitative data by classifying the data into categories of the coding frame. Qualitative data analysis is used when the meaning of the text is not obvious and requires a certain degree of interpretation from which the categories of the coding scheme are derived (Ibid.). Qualitative content analysis is used in the first step of the analysis for exploratory purposes and to define categories in the coding matrix. The coding matrix developed through the qualitative phase is the major result of this study which is additionally descriptively analyzed through quantitative content analysis. The combination of qualitative and quantitative approaches in content analysis are increasingly recommended in order to understand the studied phenomenon with grater nuance (Weber, 1990; Wimmer and Dominick, 2011, p. 118).

\section{Sample}

The sample was constructed out of full original scientific articles (minus conference papers) that covered the topics of media, communication and journalism published in the most important Croatian social science journals in the period 1969-2011: Naše teme (4 articles) and Kulturni radnik (2 articles), both discontinued in 1990, Politička misao (published from 1964, 33 articles), Društvena istraživanja (published from 1992, 4 articles) and Informatologia (published from 1969 to 1990 by the name Informatologia Yugoslavica, now published as Informatologia, 23 articles). Also included were the journals devoted exclusively to media and communication studies: Medijska istraživanja (published from 1995, 56 articles), Medianali (published from 2007, 43 articles), and Medijske studije (published from 2010, 2 articles). We also included social science journal Revija za sociologiju (published from 1971), but no articles about journalism appeared in that journal during the time period under examination. After analyzing all the articles, only those that mentioned journalism, journalists and terms closely connected to journalism in the ab- 
stract or key words ${ }^{6}$ were selected - we identified a total of 167 articles: 24 articles published in the period from 1969 to 1990, 38 articles published from 1991 to 1999, and 105 articles published from 2000 to 2011. The highest number of articles came in the years of the new millennia, probably due to the, in the academic terms, still unstudied profession in socialist Croatia, but also due to the lack of specialized media and communication journals that appeared only in the middle of the 1990s or after 2000 .

\section{Coding Process}

The analysis was done by the authors in two phases. The first phase included a qualitative content analysis of 20 articles to define the coding matrix. In the first phase, the interpretative categories were developed which were used as categories in the second, quantitative phase of the analysis. The sample of 20 articles $(12 \%$ of the total sample) in the first phase of research was developed based on diversity criteria. The sample represented diversity in three periods (socialism, transition, and consolidation) and journals. In the first step, we were, following Boyatzis (1998) steps in identifying themes or categories in the material, reading and introducing themselves to the material to recognize themes, which were then extracted and labeled as categories or codes. ${ }^{7}$ These categories or codes were used as categories in the coding matrix used in the following content analysis.

In the second phase the 167 articles were analyzed by a coding matrix consisting of a thematic focus (journalistic norms, regulation, sensationalism, investigative journalism, journalism and PR, organizational aspects, war reporting, technological aspects, gender and journalism, media freedom, democratic aspects, economic aspects, journalism education, the function of journalism in political system and journalism history) and journalism normative roles (gatekeeper, social-political worker, public sphere promoter, watchdog, commercial role, emancipatory role, neutral disseminator, advocacy role, and defender of democracy). The quantitative content analysis was performed with SPSS software and the use of descriptive statistics. The results of the analysis are twofold: the qualitative analysis resulted with a the-

${ }^{6}$ The sampling process was slightly different with journals published in the socialist period. Some of the journals did not have categorized published articles, nor requested abstract or key words, so the authors determined if the article dealt with journalism by examining the text itself. Moreover, in the socialist period authors sometimes used different terms for journalists (e.g., information worker, or social-political worker), so this was kept in mind when choosing appropriate articles for the sample.

7 According to Boyatzis (1998, p. 11), there are five steps in inductive code development: "(a) reducing the raw information, (b) identifying themes within subsamples, (c) comparing themes across subsamples, (d) creating a code, and (e) determining the reliability of the code." 
matic focus associated with journalism and normative roles, while the quantitative analysis resulted with frequencies of these categories and their distribution over three periods: socialism, transition and consolidation.

\section{Qualitative Results: Thematic Focus and Journalism Normative Roles}

Through the initial coding process, we first recognized all the manifest themes regarding the journalism profession, which were later merged in a smaller, more parsimonious set of categories. For example, the themes of media market and media ownership were merged together in the category of the economic aspects of journalism. Over the course of analysis, in total 15 different recurring journalism thematic focuses were identified: journalistic norms (ethics and norms of the journalist profession, including: deontology, responsibility of journalists and credibility), regulation (including the self-regulation of the profession), sensationalism (tabloidization, commercialization, infotainment), investigative journalism, journalism and PR (the relationship between journalism, public relations and marketing), organizational aspects (editorial process, journalistic sources and practices of collecting information), war reporting, technological aspects (digital technologies and journalism, convergence), gender and journalism, media freedom (censorship, self-censorship, the right to obtain information), democratic aspects (journalism and democracy, journalism and transition to democracy), economic aspects (ownership, market and journalism), journalism education, the function of journalism in the political system (the function of journalism in the specific self-management socialism in Yugoslavia) and journalism history.

In the coding process nine different journalism normative roles were identified. The role was coded as a normative role if in the analyzed article it was portrayed in a positive manner, as a desirable practice, or as an expectation that journalists should follow or have as a function. Some articles did not engage in normative definitions of journalism roles. In some articles in the sample, there were explicit references to, for example, "the watchdog" role that journalists should assume, but in other cases they referred to the specific practices which were coded under a certain category while not being explicitly mentioned (e.g. if the authors emphasized the importance of monitoring or criticizing those in power, this was coded as a watchdog role). The final list of categories found during the coding process consists mostly of already theoretically acknowledged roles, but some are specific to the Yugoslav or Croatian context. The gatekeeper role was in most cases explicitly referred to in articles, but all the articles in which the importance of the journalism profession in extracting relevant, reliable or trustworthy information is emphasized are coded as expressing the normative gatekeeper role. Public sphere promoter was coded in cases where the importance of journalism for deliberation, setting the agenda or the promotion 
of the public sphere was emphasized. The watchdog role was coded for cases when authors defined criticizing or monitoring the power or investigative journalism as a desirable journalistic practice. The commercial role pertained to the cases where aligning to the needs of the market or ratings was perceived as important for the journalism profession. In some cases, authors emphasized the need of journalists to speak on behalf of empowering the less privileged or marginalized social groups in these cases this normative role was coded as emancipatory. If the values of neutrality, impartiality or objectivity were pinpointed as a desirable or positive aspect of the profession, these aspects were coded under the neutral disseminator role. The advocacy role was recognized in articles in which advocating or promoting certain causes, issues or attitude was portrayed as a positive aspect of the profession.

Social-political worker is a normative role specific for the socialist period. As social-political worker was a term commonly used for journalists in the period, very often this role was explicitly referred to as such. The social-political worker was perceived as an essential part of the political system, with internalized values of the socialist system and provided information relevant for the functioning of the complex self-management system. For example, in one of the analyzed articles, there is a description of journalism in Yugoslavia's socialist system:

If objective blame for shortcomings in journalistic interpretations lies in the absence of a relevant socialist system of social values, then politics is not the only one to blame, because all of us are arguably guilty together, including the press (...) and in contrast to it [the late capitalistic value system], the only clear and generally accepted social value in socialism is: "No more turning back. Starting from the achievements of socialism, there is no way back, to restore capitalism." (Peratoner, 1973, p. 2014) ${ }^{8}$

Defender of democracy is a specific normative role emerged during the transition period, that perceives journalists as defenders of democracy, rule of law and (national/cultural) identity. It is somewhat similar to the advocacy role, but was distinguished as specific for the transition to the democracy period. This role is somewhere in between the Hanitzsch and Vos (2018) developmental-educational function in which journalists are social change agents, and educators of democratic values in the transition to the new system, but it also has some characteristics of the collaborative-facilitative function, in understanding journalism as assisting government in the development and nation-building process. This role relates to the thematic focus of democratic aspects, as it assumes the journalist to hold a function of legitimizing the democratic system. In the next section, the results of the content

${ }^{8}$ All the quotes taken as examples of categories were translated from Croatian to English by the authors. 
analysis portray the dominance of certain thematic focuses and roles across the three time periods.

\section{The Distribution of Thematic Focuses in Articles About Journalism in Three Periods}

The most common thematic focus in the socialist period is the function of journalism in the political system (27\%), a theme specific for the period as it described the importance of journalists as information or social-political workers with a role to promote and distribute information to ensure a better functioning of the self-management socialist system (the frequencies and percentages of themes inside and across time periods can be found in Table 1 in the Appendix). It is also a thematic focus not found in the two remaining analyzed periods, which at first indicates that the function was not at all analyzed, even within the position of the critique of the system itself.

The next prevalent theme in socialism is the organizational aspect of journalism $(22 \%)$ which deals with the editorial process, newsroom and practical journalism work. A peculiarity of the period is the fact that as high as five thematic focuses found in the other two periods did not at all appear during socialism (investigative journalism, journalism and public relations, war reporting, journalism and gender, and journalism history). For some of these there are clear explanations. The connection between journalism and public relations only became a topic at the beginning of the new millennium. Even though there have been traces of public relations in Croatia since the 1960s (Tomašević, 2002, p. 9, as quoted in Skoko, 2004, p. 72), the real bloom of the profession came only after 2000 (Skoko, 2004, p. 72) so these results (in terms of the academic study of the journalism - PR relationship) were expected.

Interestingly, out of all the articles on economic aspects, 25\% were published during socialism. This demonstrates the preoccupations with economic aspects in a specific economic system. Several articles tackled the topic of "Vjesnik", a publishing company that experienced its golden age from 1965 to 1971 (Novak, 2005, p. 559) and, within the socialist economy, operated as a real capitalist institution. ${ }^{9}$ Another result that speaks in favor of the inappropriate unilateral interpretation of the socialist period is a total $10 \%$ of the articles on media freedom that appeared in

9 A publication on the profiles of readerships published in 1976 by "Vjesnik" to better understand their audiences and market their products serves as a confirmation of this (Mance, 1976). "Vjesnik" publishing company enjoyed a high level of autonomy in terms of its relationship with its founder, the Socialist Alliance of Working People (Socijalistički savez radnog naroda) (Senjković, 2008, p. 49). Also important was the more liberal media policy brought about in the 1960s which encouraged the financial independence of media from state funding and a reliance on advertising (Mihelj, 2014, p. 12). 
Figure 1. Journalism Thematic Focus Distribution in Three Periods

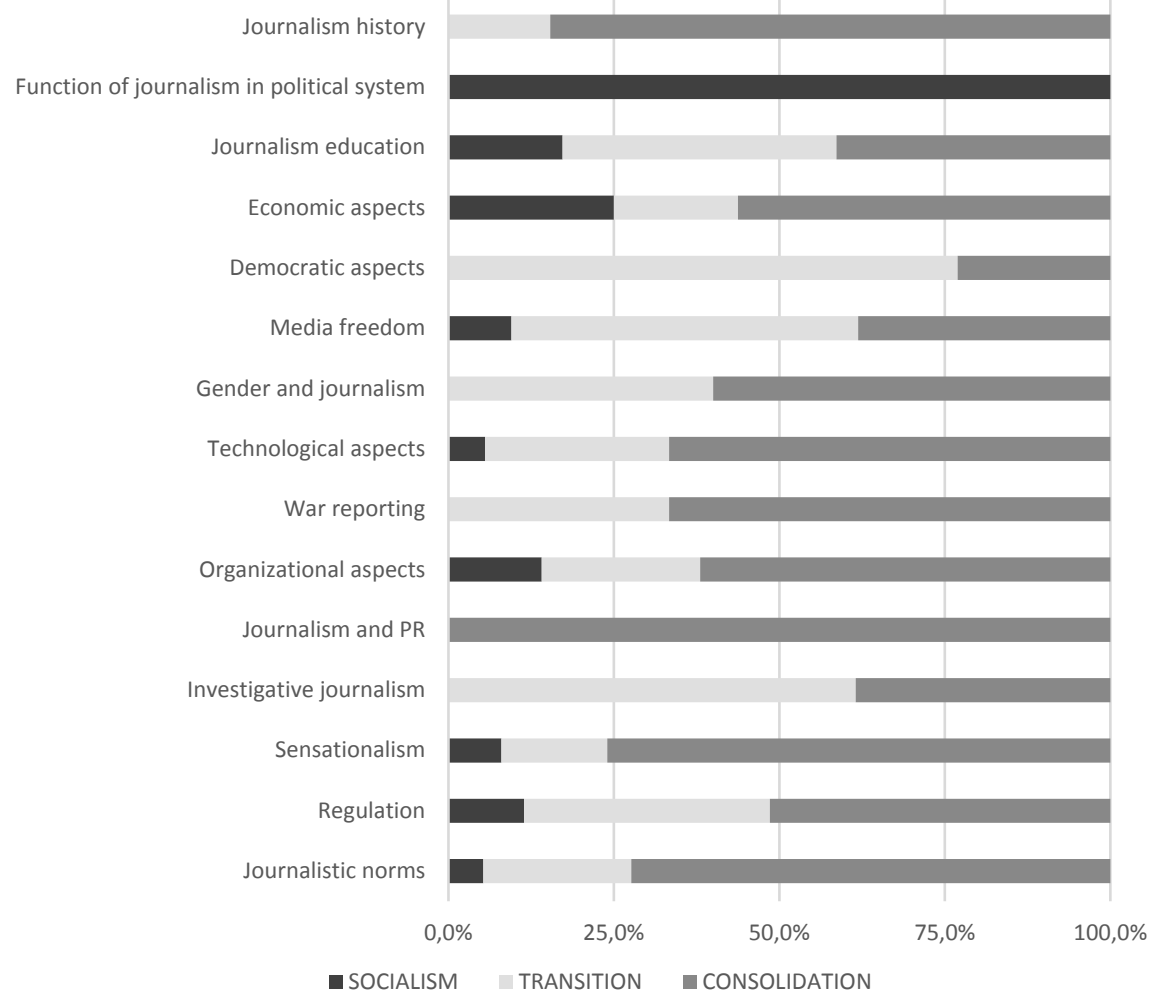

the period. An explanation for this result could be viewed in terms of the gradual liberalization of the Yugoslav public sphere (Mihaljević, 2015), especially in the second half of the 1980s in Yugoslavia, the time of the policies that eased the state's grip on the media.

Certain themes gained more prominence in transition: democratic aspects (77\%), investigative journalism (62\%) and media freedom (52\%) (Table 1 in the Appendix). Such results were expected since the 1990s were the time in which democracy was being established, but despite the illusion of freedom, most of the media were tightly in the hands of the ruling political party (HDZ or Croatian Democratic Union). Attention to investigative journalism in the transition period might also be a part of the normative stance in the academic literature of the period, which emphasized the desired models of journalism in (Western) liberal democracies, or to draw a parallel with Hanitzsch's (2011) research, the detached watchdog role of journalists. These three themes alone are more aligned with the position of media 
and journalism in narrower models of democracy (Strömbäck, 2005). The theme of democratic aspects points to the role of academic elites in the transitional period: media were considered not only institutions that should be democratized, but instruments of democratization themselves, legitimizing the new political system. Journalism and media, in this sense, had been seen as functionaries of the political system, however in the transitional phase the self-managed socialism was replaced by liberal democracy.

The themes democratic aspects and media freedom could be illustrated by the following quote from the analyzed material:

In the developed world, with centuries old democratic tradition and media freedom it is surely easier to accomplish that [professional journalism education] than in Central and Eastern European countries which started developing democracy, a multiparty system, freedom of speech and media freedom... (Vilović, 1999, p. 205)

The same author then quotes the handbook on journalism training (Gaunt, 1992, in Ibid., p. 206) where it is claimed that: "The function of journalism in Central and Eastern Europe and their path towards democratic society, free market and basic media freedoms is not the same as in the West."

While normative themes like democratic aspects or media freedom were mostly prevalent in the transition period, the consolidation period is marked with themes concerning the definition of the journalism field (journalistic norms and organizational aspects) or perceived problems or challenges for the journalism profession (sensationalism or technological aspects). In the consolidation period, when media and journalism as democratic institutions were expected to adhere to the rules of a market economy and a democratic political system, the academic focus switched to the functioning of the journalistic field itself. For this reason, themes of journalistic norms and organizational aspects, closer to the autonomous pole of the journalism field were discussed. However, themes such as sensationalism, economic aspects or PR and journalism point to the movement of the journalism field to the economic field. The explanation for a high number of articles on sensationalism in the consolidation period $(76 \%$ of all the articles on sensationalism were published in that period) can be given in the context of the emergence of tabloidization in Croatia, the full swing of which came at the end of the 1990s, with the emergence of semi tabloid daily newspaper Jutarnji list (in 1998) that heavily influenced other papers in terms of presentation of content (Vilović, 2004, p. 53) and later with 24sata as a classic tabloid (in 2005).

The consolidation period was also marked with the stronger liberalization of media in terms of ownership and licenses when more national and international private print and electronic media gained shares in the market. The growing tabloidization could also be the reason for the rise in the academic study of journalistic norms 
( $72 \%$ of the articles on journalistic norms were published in the consolidation period) as the category included journalism ethics and the question of credibility and responsibility of journalists. It is also the most common theme inside the consolidation period $(24 \%)$.

When looking at shares of the themes across analyzed time periods we see $85 \%$ of the articles on journalism history, $67 \%$ of the articles on both technological aspects and war reporting, $62 \%$ of the articles on the organizational aspects of journalism, and $60 \%$ of the articles on gender and journalism were published during the consolidation period. The highest number of articles about the economic aspects of journalism were published in the consolidation period (56\%), which might as well point to the movement of the journalism field to the economic field.

\section{The Distribution of Normative Roles of Journalists in Three Periods}

Expectedly (after the preliminary analysis) the most common normative role for journalists in socialism was the role of social-political worker (38\%) (the frequencies and percentages of normative roles inside and across time periods can be found in Table 2 in the Appendix). In one of the analyzed articles there is a representative description of the role of journalists in socialism:

[they] cannot complement or be a part of the checks and balances of a political system [but still] they are within its function and therefore in a function of the Socialist alliance. They cannot replace the entire system. But it should be noted that they can express the entire democratic content of the society and interests it derives. (Pištalo, 1970, p. 112)

However, the next normative role in socialism was the neutral disseminator (31\%). Since most of the articles with this normative role were published in the second part of the 1980s, the results are again explained by the changes in society and the political system. In the 1980s the political influences on media were less harsh and some republics in Yugoslavia experienced more media freedoms than others and saw the establishment of critical, alternative media. Moreover, the communication discipline became more diversified in this period, so the emergence of this theme in the 1980s might also be a result of broader themes being discussed in the academic literature in this period in general (Peruško and Vozab, 2014). Perhaps also unexpectedly, the commercial role appears as the normative role of journalists in the socialist period. This refutes the generalized unidimensional notion of the journalist as a social-political worker in socialist systems as the literature often suggests. As it was already noted, the media system in Yugoslavia was liberalized in certain aspects in the 1960s, and media partly functioned according to a market logic, thus the commercial role was also considered as desirable by certain authors, especially those in some way connected with media companies. 
Figure 2. Normative Journalism Roles Distribution in Three Periods

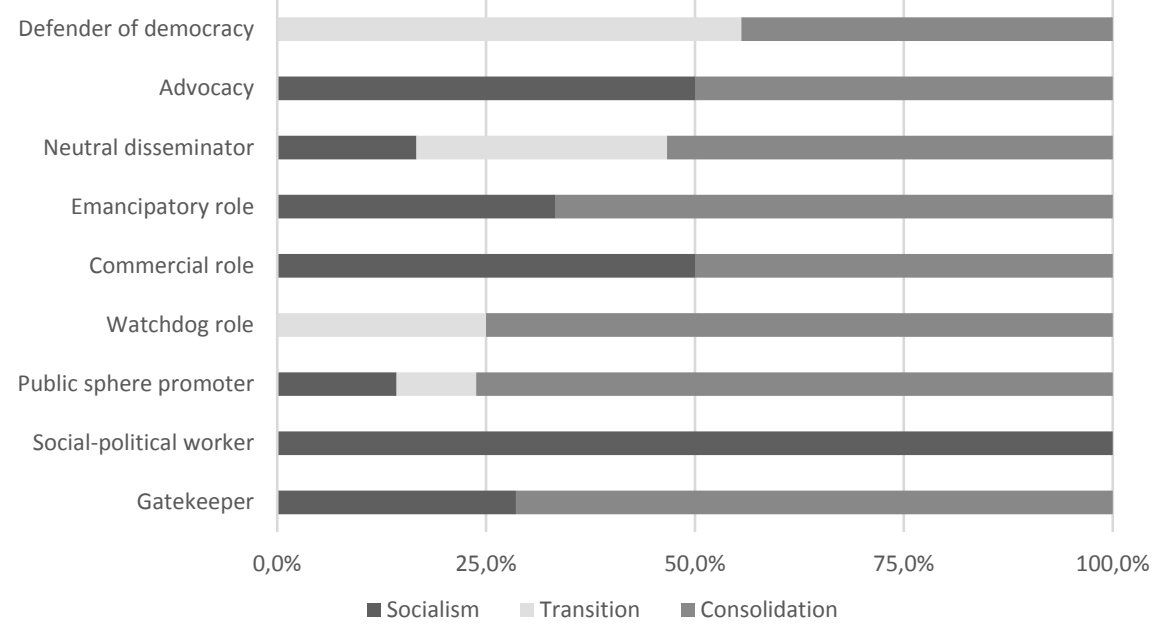

The articles in the transition period are marked by a stark decline in both the number of articles and the amount of research produced, as well as in the quality of published articles (Ibid.). This is also followed by less diverse research topics and a narrower focus, exemplified here by focusing only on normative roles connected with democratization. In the transition period, only four normative roles for journalists appeared - public sphere promoter, watchdog, neutral disseminator, and defender of democracy, all connected to the roles expected of journalists in narrower models of democracy (Strömbäck, 2005) except the public sphere promoter role, which is suitable to broadened models of democracy. This is perhaps best summarized in the following citation:

Democracy without the professional mass media which supply citizens with important information and act as watch-dogs against authority is not democracy, the same as journalism without respecting the ethical demands and carrying out the mission of the true and genuine informing of the public is not journalism. (Poler Kovačič, 1997, p. 15)

In the transition period the dominant normative role is the neutral disseminator $(62 \%)$, but what is more interesting is the role of journalists as defenders of democracy. Inside this period the role of defender of democracy appears in 17\% of articles (56\% when analyzing published articles across all three periods). An example for this role is the following citation from the analyzed material: "As a term and practice, democratic journalism is defined as the one that discusses a path towards 
the development of society according to contemporary civilization's values" (Perić, 1997, p. 217).

The same link as the one between the function of journalism in a political system (socialism) and democratic aspects (transition), could be made between journalists as social-political workers and journalists as defenders of democracy. Journalism is considered not only as an autonomous institution providing checks and balances to the democratic system, but as having an active role in democratization, introducing and ensuring the acceptance of democratic principles and values to elites and citizens, similar to the developmental-educational function of journalism (as in Hanitzsch and Vos, 2018).

The highest number of different roles for journalists appeared in the consolidation period (all except social-political worker). This corresponds to the growth and diversification of journals and research topics in media and communication science in Croatia in the 2000s (Peruško and Vozab, 2014). The most important role was the neutral disseminator ( $42 \%$ in the analyzed period); this role is also dominant when compared across time periods, nevertheless it is the most evenly distributed role ( $17 \%$ socialism, $30 \%$ transition, $53 \%$ consolidation). The following citation is a notable example for the specific role:

For the media it means an obligation of active reporting; research and the collection of informative facts sufficient for qualified election decisions, checking the accuracy and completeness of self-presenting messages of political subjects, opening and imposing the topics of public interest, value interpretation, the confrontation of relevant candidates, and assessing the actual capacity to keep promises. (Kurtić, 2007, p. 147)

In comparison to other analyzed periods, there is a diversity of roles in the consolidation period that were also the dominant ones when looking at shares of individual roles across the analyzed time periods: gatekeeper $(71 \%$ in the consolidation period, and not at all present in the transition period); public sphere promoter $(76 \%$ in consolidation, almost equally rarely present in socialism and transition); watch$\operatorname{dog}(75 \%$ in the consolidation period, $25 \%$ in the transition period), and emancipatory ( $67 \%$ in the consolidation period, interestingly $33 \%$ during socialism). In the consolidation period the different democratic roles of journalists are present, but unlike the transition period with the focus on roles appropriate only to narrower models of democracy, in the consolidation period these roles are broadened. For example, in the consolidation period the role of journalists in setting the agenda and promoting the public sphere is strongly emphasized. The difference from the transition period is also a more critical stance taken by some authors in the consolidation period. While in the transition period the linear democratization and transition to a 
free market is often taken as almost an unquestioned value, in the consolidation period more diverse and critical approaches to democracy and the market are present. An example could be found in the following quote:

The realization of the idea of the blog has at its core the right to communicate (...) they also influence the agenda-setting of traditional media (...) Where the longestablished normative principles of the fourth estate stress the importance of objectivity, restraint and understatement, bloggers are aggressively opinionated, prepared to expose their views to public scrutiny and engage others in the fierce heat of online debate (McNair, 2006: 122). (Vobič, 2007, p. 64) ${ }^{10}$

\section{Discussion and Conclusion}

The goal of this paper was to explore the academic perception of journalism in terms of the themes connected to journalism and the normative roles of journalists, and to analyze the transformation of this perception in the socialist, transition and consolidation periods. In order to answer the first two research questions, qualitative content analysis provided fifteen journalistic thematic focuses and nine normative roles for journalists, while the third research question was answered by using quantitative analysis and measuring the distribution of journalism roles and themes across time periods.

The study suggests no unidimensional normative role for journalists appeared in the academic literature in the different analyzed time periods. Although the social-political worker role was dominant in the socialist period, other roles such as neutral disseminator and even a commercial role appear in this period as well. This is consistent with previous research which found an adherence to liberal norms of Polish journalists in the socialist period (Stępińska and Ossowski, 2012). Similarly to the normative roles, there is a certain diversity of themes associated with journalism in the socialist period. Although the prevalent theme is the function of journalism in self-management socialism, themes connected to the organizational, economic, technological aspects, or media freedom are also present in the period. Therefore, these results evade the West/East binary often present in discourse about the democratization of post-socialist media systems in which media in socialism are perceived as "a tool of state propaganda in the service of ideological goals, as a cultural form subordinated to party politics, devoid of entertainment and immensely dull, yet also somehow hugely powerful and capable of turning audiences into obedient party subjects" (Mihelj, 2014, p. 9).

Dominant themes and roles in the transition period are closely connected to the process of media democratization. The dominant normative roles for journal-

10 This article is originally published in English, so no translation by the authors was needed. 
ists changed in this period, with neutral disseminator as the most important. Nevertheless, an important role in this period is defender of democracy. This is a role characteristic for the transition period, which in its function bears similarities to the social-political worker, as it too emphasizes the more interventionist role of journalists in ensuring the functioning of the political system. However, in the case of defenders of democracy, journalists are expected to promote the democratic values and legitimize the democratic political system. According to the democratization perspective in media systems, media are also seen as instruments of democratization of the political system. This role is consistent with this perspective. Thus, the normative approach to journalism emphasizes its functioning within the political systems, rather than acting as a purely autonomous field.

The main characteristic of the consolidation period is the diversification of both journalism themes and roles. In this period, we see a shift of academic focus on themes regarding the journalism profession itself, like journalistic norms and organizational aspects. Besides these themes, the contemporary global challenges to the journalism profession are also an important issue in this period, such as the technological aspects of journalism and trends such as sensationalism. This period is marked by a broader acknowledgement of journalism roles, not just in the perspective of narrower democratic models like in the transition period, but also from the expanded definition of the roles of journalists in democracy.

If journalism is conceptualized as a field, from the perspective of the analyzed academic literature it could be interpreted as one connected more closely to the political field in both the socialist and the transition periods. In those periods, journalism roles are conceptualized primarily in the function of the political system, being either socialist or democratic. On the other hand, in the consolidation period there is a stronger shift towards the normative definitions and a focus on the autonomous role of the journalism field itself.

The limitations of our research are in the sample as it consists of academic production only in Croatia, which cannot be taken for a generalization about the entire normative approach to the post-socialist transformation of journalism. Additionally, the combination of qualitative and quantitative analysis in this research provided definitions and frequencies of certain thematic focuses and normative roles of journalism in academic literature, but a more thorough qualitative analysis is needed in order to describe the meaning of these categories in a deeper manner. However, this preliminary research opens a venue for further investigation of the transition of journalism normative roles. 


\section{Appendix}

Table 1. Journalism Thematic Focus Distribution in Three Periods

\begin{tabular}{|c|c|c|c|c|c|c|c|c|c|}
\hline \multirow{2}{*}{$\begin{array}{c}\text { JOURNALISM } \\
\text { THEMATIC } \\
\text { FOCUS }\end{array}$} & \multicolumn{3}{|c|}{ SOCIALISM } & \multicolumn{3}{|c|}{ TRANSITION } & \multicolumn{3}{|c|}{ CONSOLIDATION } \\
\hline & $\mathrm{N}$ & $\begin{array}{c}\% \text { across } \\
\text { periods }\end{array}$ & $\begin{array}{c}\% \text { inside } \\
\text { period }\end{array}$ & $\mathrm{N}$ & $\begin{array}{c}\% \text { across } \\
\text { periods }\end{array}$ & $\begin{array}{c}\% \text { inside } \\
\text { period }\end{array}$ & $\mathrm{N}$ & $\begin{array}{c}\% \text { across } \\
\text { periods }\end{array}$ & $\begin{array}{c}\% \text { inside } \\
\text { period }\end{array}$ \\
\hline Journalistic norms & 4 & $5 \%$ & $9 \%$ & 17 & $22 \%$ & $15 \%$ & 55 & $72 \%$ & $24 \%$ \\
\hline Regulation & 4 & $11 \%$ & $9 \%$ & 13 & $37 \%$ & $12 \%$ & 18 & $51 \%$ & $8 \%$ \\
\hline Sensationalism & 2 & $8 \%$ & $4 \%$ & 4 & $16 \%$ & $4 \%$ & 19 & $76 \%$ & $8 \%$ \\
\hline $\begin{array}{l}\text { Investigative } \\
\text { journalism }\end{array}$ & 0 & $0 \%$ & $0 \%$ & 8 & $62 \%$ & $7 \%$ & 5 & $38 \%$ & $2 \%$ \\
\hline Journalism and PR & 0 & $0 \%$ & $0 \%$ & 0 & $0 \%$ & $0 \%$ & 17 & $100 \%$ & $7 \%$ \\
\hline $\begin{array}{l}\text { Organizational } \\
\text { aspects }\end{array}$ & 10 & $14 \%$ & $22 \%$ & 17 & $24 \%$ & $15 \%$ & 44 & $62 \%$ & $19 \%$ \\
\hline War reporting & 0 & $0 \%$ & $0 \%$ & 2 & $33 \%$ & $2 \%$ & 4 & $67 \%$ & $2 \%$ \\
\hline $\begin{array}{l}\text { Technological } \\
\text { aspects }\end{array}$ & 2 & $6 \%$ & $4 \%$ & 10 & $28 \%$ & $9 \%$ & 24 & $67 \%$ & $10 \%$ \\
\hline $\begin{array}{l}\text { Gender and } \\
\text { journalism }\end{array}$ & 0 & $0 \%$ & $0 \%$ & 2 & $40 \%$ & $2 \%$ & 3 & $60 \%$ & $1 \%$ \\
\hline Media freedom & 2 & $10 \%$ & $4 \%$ & 11 & $52 \%$ & $10 \%$ & 8 & $38 \%$ & $3 \%$ \\
\hline $\begin{array}{l}\text { Democratic } \\
\text { aspects }\end{array}$ & 0 & $0 \%$ & $0 \%$ & 10 & $77 \%$ & $9 \%$ & 3 & $23 \%$ & $1 \%$ \\
\hline Economic aspects & 4 & $25 \%$ & $9 \%$ & 3 & $19 \%$ & $3 \%$ & 9 & $56 \%$ & $4 \%$ \\
\hline $\begin{array}{l}\text { Journalism } \\
\text { education }\end{array}$ & 5 & $17 \%$ & $11 \%$ & 12 & $41 \%$ & $11 \%$ & 12 & $41 \%$ & $5 \%$ \\
\hline $\begin{array}{c}\text { Function of } \\
\text { journalism in } \\
\text { political system }\end{array}$ & 12 & $100 \%$ & $27 \%$ & 0 & $0 \%$ & $0 \%$ & 0 & $0 \%$ & $0 \%$ \\
\hline Journalism history & 0 & $0 \%$ & $0 \%$ & 2 & $15 \%$ & $2 \%$ & 11 & $85 \%$ & $5 \%$ \\
\hline
\end{tabular}


Table 2. Normative Journalism Roles Distribution in Three Periods

\begin{tabular}{|c|c|c|c|c|c|c|c|c|c|}
\hline \multirow{2}{*}{$\begin{array}{c}\text { JOURNALISM } \\
\text { ROLES }\end{array}$} & \multicolumn{3}{|c|}{ SOCIALISM } & \multicolumn{3}{|c|}{ TRANSITION } & \multicolumn{3}{|c|}{ CONSOLIDATION } \\
\hline & $\mathrm{N}$ & $\begin{array}{l}\% \text { across } \\
\text { periods }\end{array}$ & $\begin{array}{c}\% \text { inside } \\
\text { period }\end{array}$ & $\mathrm{N}$ & $\begin{array}{l}\% \text { across } \\
\text { periods }\end{array}$ & $\begin{array}{c}\% \text { inside } \\
\text { period }\end{array}$ & $\mathrm{N}$ & $\begin{array}{c}\% \text { across } \\
\text { periods }\end{array}$ & $\begin{array}{l}\% \text { inside } \\
\text { period }\end{array}$ \\
\hline Gatekeeper & 2 & $29 \%$ & $6 \%$ & 0 & $0 \%$ & $0 \%$ & 5 & $71 \%$ & $7 \%$ \\
\hline $\begin{array}{l}\text { Social-political } \\
\text { worker }\end{array}$ & 12 & $100 \%$ & $38 \%$ & 0 & $0 \%$ & $0 \%$ & 0 & $0 \%$ & $0 \%$ \\
\hline $\begin{array}{l}\text { Public sphere } \\
\text { promoter }\end{array}$ & 3 & $14 \%$ & $9 \%$ & 2 & $10 \%$ & $7 \%$ & 16 & $76 \%$ & $21 \%$ \\
\hline Watchdog role & 0 & $0 \%$ & $0 \%$ & 4 & $25 \%$ & $14 \%$ & 12 & $75 \%$ & $16 \%$ \\
\hline Commercial role & 2 & $50 \%$ & $6 \%$ & 0 & $0 \%$ & $0 \%$ & 2 & $50 \%$ & $3 \%$ \\
\hline Emancipatory role & 2 & $33 \%$ & $6 \%$ & 0 & $0 \%$ & $0 \%$ & 4 & $67 \%$ & $5 \%$ \\
\hline Neutral disseminator & 10 & $17 \%$ & $31 \%$ & 18 & $30 \%$ & $62 \%$ & 32 & $53 \%$ & $42 \%$ \\
\hline Advocacy & 1 & $50 \%$ & $3 \%$ & 0 & $0 \%$ & $0 \%$ & 1 & $50 \%$ & $1 \%$ \\
\hline $\begin{array}{l}\text { Defender of } \\
\text { democracy }\end{array}$ & 0 & $0 \%$ & $0 \%$ & 5 & $56 \%$ & $17 \%$ & 4 & $44 \%$ & $5 \%$ \\
\hline
\end{tabular}

\section{REFERENCES}

Andresen, Kenneth, Abit Hoxha, and Jonila Godole. (2017). New Roles for Media in the Western Balkans. Journalism Studies. doi: 10.1080/1461670X.2016.1268928

Balčytienè, Aukse. (2016). The Price of Liberalisation and Other Strains on Democracy and Media Freedom in Central and Eastern Europe, in: Terry Flew, Petros Iosifidis, and Jeanette Steemers (eds): Global Media and National Policies. The Return of the State. Palgrave Macmillan. Basingstoke: 206-225.

Benson, Rodney. (1998). Field Theory in Comparative Context: A New Paradigm for Media Studies. Theory and Society, (28), 3: 463-498.

Blumler, Jay G., and Michael Gurevitch. (1995). The Crisis of Public Communication. Routledge. London, New York.

Boduszynski, Mieczyslaw. (2010). Regime Change in the Yugoslav Successor States. Divergent Paths toward new Europe. John Hopkins University Press. Baltimore.

Boyatzis, Richard E. (1998). Transforming qualitative information: Thematic analysis and code development. SAGE Publications. London. 
Carothers, Thomas. (2002). The End of the Transition Paradigm. Journal of Democracy, (13), 1: 5-21.

Christians, Clifford G., Theodore L. Glasser, Denis McQuail, Kaarle Nordenstreng, and R. A. White. (2009). Normative Theories of the Media. University of Illinois Press. Chicago.

Coman, Mihai. (2000). Developments in Journalism Theory About Media "Transition" in Central and Eastern Europe 1990-99. Journalism Studies, (1), 1: 35-56. doi: $10.1080 / 146167000361168$

Čular, Goran. (2000). Political Development in Croatia 1990-2000: Fast Transition Postponed Consolidation. Politička misao, (37), 5: 30-46.

Deuze, Mark. (2005). What is journalism? Professional identity and ideology of journalists reconsidered. Journalism, (6), 4: 442-464. doi: 10.1177/1464884905056815

Gans-Morse, Jordan. (2004). Searching for Transitologists: Contemporary Theories of Post-Communist Transitions and the Myth of a Dominant Paradigm. Post-Soviet Affairs, (20), 4: 320-349.

Gross, Peter. (2004). Between Reality and Dream: Eastern European Media Transition, Transformation, Consolidation, and Integration. East European Politics and Societies, (18), 1: 110-131.

Hallin, Daniel C., and Paolo Mancini. (2004). Comparing media systems: three models of media and politics. Cambridge University Press. Cambridge, New York.

Hanitzsch, Thomas. (2007). Deconstructing Journalism Culture: Toward a Universal Theory. Communication Theory, (17), 4: 367-385. doi: 10.1111/j.14682885.2007.00303.x

Hanitzsch, Thomas. (2011). Populist Disseminators, Detached Watchdogs, Critical Change Agents and Opportunist Facilitators: Professional Milieus, the Journalistic Field and Autonomy in 18 Countries. International Communication Gazette, (73), 6: 477-494. doi: https://doi.org/10.1177/1748048511412279

Hanitzsch, Thomas, Folker Hanusch, Claudia Mellado, Maria Anikina, Rosa Berganza, Incilay Cangoz, Mihai Coman et al. (2011). Mapping Journalism Cultures Across Nations: A comparative study of 18 countries. Journalism Studies, (12), 3: 273-293. doi: http://dx.doi.org/10.1080/1461670X.2010.512502

Hanitzsch, Thomas and Tim P. Vos. (2018). Journalism beyond democracy: A new look into journalistic roles in political and everyday life. Journalism, (19), 2: 146-164.

Herrero, Laia C., Edda Humprecht, Sven Engesser, Michael L. Brüggemann, and Florin Büchel. (2017). Rethinking Hallin and Mancini beyond the West: An analysis of media systems in Central and Eastern Europe. International Journal of Communication, (11), 27: 4797-4823.

Jakubowicz, Karol, and Miklós Sükösd. (2008). Finding the Right Place on the Map. Central and Eastern European Media Change in a Global Perspective. Intellect. Bristol, UK, Chicago, USA. 
Jebril, Nael, Matthew Loveless, and Vaclav Stetka. (2015). Media and Democratization: Challenges for an Emerging Sub-field. Media Studies, (6), 11: 84-98.

Jernigan, David H., and Patricia A. Wright. (1996). Media Advocacy: Lessons from Community Experiences. Journal of Public Health Policy, (17), 3: 306-330. doi: $10.2307 / 3343268$

Kurtić, Najil. (2007). Mediji i izbori. Medianali, (1), 2: 139-148.

Law on public informing (Zakon o javnom informiranju s objašnjenjem i osnovnom listom informacija u udruženom radu). (1982). Novinsko izdavačka radna organizacija "Radničke novine". Zagreb.

Lewin, Kurt. (1947). Frontiers in Group Dynamics: II. Channels of Group Life; Social Planning and Action Research. Human Relations, (1), 2: 143-153.

Mance, Gordana. (1976). Profili čitalačkih publika. Vjesnik. Zagreb.

Mihaljević, Josip. (2015). Liberalizacija i razvoj medija u komunističkoj Hrvatskoj 1960-ih i na početku 1970-ih. Društvena istraživanja, (24), 2: 239-258.

Mellado, Claudia, and Arjen Van Dalen. (2017). Changing Times, Changing Journalism: A Content Analysis of Journalistic Role Performances in a Transitional Democracy. The International Journal of Press/Politics, (22), 2: 244-263. doi: $10.1177 / 1940161217693395$

Mihelj, Sabina. (2014). Understanding Socialist television: concepts, objects, methods. VIEW: Journal of European Television History and Culture, (3), 5: 7-16.

Mihelj, Sabina, and Simon Huxtable. (2018). From media systems to media cultures: Understanding socialist television. Cambridge University Press. Cambridge.

Novak, Božidar. (2005). Hrvatsko novinarstvo u 20. stoljeću. Golden marketingTehnička knjiga. Zagreb.

Peratoner, Ervin. (1973). Funkcija, mjesto i moć masovnih sredstava informiranja i komuniciranja u društvenom životu Hrvatske. Naše teme, (17), 12: 2005-2014.

Perić, Jože. (1997). Vlasnička demokracija i demokratsko novinarstvo u Republici Hrvatskoj. Informatologia, (29/30), 1-4: 217-220.

Peruško, Zrinjka. (2013). Komparativna analiza postsocijalističkih medijskih sustava. Politička misao, (50), 2: 38-59.

Peruško, Zrinjka, Dina Vozab, and Antonija Čuvalo. (2013). Audiences as a Source of Agency in Media Systems: Post-socialist Europe in Comparative. Medialni studia, (14), 2: 1-22.

Peruško, Zrinjka, and Dina Vozab. (2014). Povijest komunikacijskih i medijskih studija u Hrvatskoj: Politička misao u komparativnoj perspektivi. Politička misao, (51), 1: 133-170.

Peruško, Zrinjka, and Dina Vozab. (2016). The field of Communication in Croatia: Toward a Comparative History of Communication Studies in Central and Eastern Eu- 
rope, in: Peter Simonson, and David W. Park (eds): The International History of Communication Study. Routledge. New York, London: 213-234.

Pištalo, Milan. (1970). Politička kultura i sredstva javnog informiranja. Politička misao, (7), 1: 109-112.

Poler Kovačič, Melita. (1997). Novinarstvo između informiranja javnosti i ostvarivanja zarade. Medijska istraživanja, (3), 1-2: 9-17.

Robinson, Gertrude J. (1977). Tito's Maverick Media: The Politics of Mass Communications in Yugoslavia. University of Illinois Press. Chicago, Urbana.

Schreier, Margrit. (2012). Qualitative Content Analysis in Practice. Sage Publications Ltd. Los Angeles.

Schudson, Michael, and Chris Anderson. (2009). Objectivity, Professionalism, and Truth Seeking in Journalism, in: Karin Wahl-Jorgensen, and Thomas Hanitzsch (eds): The Handbook of Journalism Studies. Routledge. New York, London: 88-101.

Senjković, Reana. (2008). Izgubljeno u prijenosu: Pop iskustvo soc kulture. Institut za etnologiju i folkloristiku. Zagreb.

Siebert, Fred S., Theodore Peterson, and Wilbur Schramm. (1956). Four theories of the press: the authoritarian, libertarian, social responsibility, and Soviet communist concepts of what the press should be and do. University of Illinois Press. Urbana.

Skoko, Božo. (2004). Kvantitativni i kvalitativni dosezi odnosa s javnošću u Hrvatskoj 2003. Medijska istraživanja, (10), 1: 67-82.

Splichal, Slavko. (1989). Indigenization Versus Ideologization: Communication Science on the Periphery. European Journal of Communication, (4), 3: 329-359.

Splichal, Slavko. (1994). Media Beyond Socialism: Theory and Practice in East-Central Europe. Westview Press. Boulder.

Splichal, Slavko. (2001). Imitative revolutions. Changes in the media and journalism in East-Central Europe. Javnost, (8), 4: 31-58.

Stępińska, Agnieszka, and Szymon Ossowski. (2012). Three generations of Polish journalists. Journalism Studies, (13), 5-6: 857-867. doi: 10.1080/1461670X.2012.668000

Strömbäck, Jesper. (2005). In Search of a Standard: four models of democracy and their normative implications for journalism. Journalism Studies, (6), 3: 331-345.

Vatikiotis, Pantelis. (2005). Communication Theory and Alternative Media. Westminster Papers in Communication and Culture, (2), 1: 4-26. doi: http://doi.org/10.16997/ wpcc.5

Vilović, Gordana. (1999). Novinarska radionica: Profesionalno usavršavanje - stalna potreba. Politickka misao, (36), 1: 204-227.

Vilović, Gordana. (2004). Etički prijepori u Globusu i Nacionalu, 1999-2000. Fakultet političkih znanosti. Zagreb.

Vobič, Igor. (2007). Normalizacija bloga u novinarstvu: Elektroničke novine tradicionalnih slovenskih medija. Medijska istraživanja, (13), 2: 59-82. 
Voltmer, Katrin, ed. (2006). Mass Media and Political Communication in New Democracies. Routledge. London, New York.

Weber, Robert P. (1990). Basic content analysis. Sage Publications. Newbury Park, Calif.

Wimmer, Roger D., and Joseph R. Dominick. (2011). Mass media research: an introduction (ninth edition). Cengage-Wadsworth. Boston.

Zakošek, Nenad. (2008). Democratization, State-building and War: The Cases of Serbia and Croatia. Democratization, (15), 3: 588-610. doi: 10.1080/13510340801991130

Zubak, Marko. (2018). The Yugoslav Youth Press (1968-1980). Student movements, youth subcultures and alternative communist media. Srednja Europa. Zagreb.

Mailing Addresses:

Dina Vozab, Faculty of Political Sciences, University of Zagreb, Lepušićeva 6, 10000 Zagreb.E-mail: dina.vozab@fpzg.hr

Dunja Majstorović, Faculty of Political Sciences, University of Zagreb, Lepušićeva 6, 10000 Zagreb.E-mail: dunja.majstorovic@fpzg.hr 